CURRENT ECONOMIC ISSUES - BKR

\title{
An analysis of Brazil's economic situation: 2014-2017, the short-term outlook and policy alternatives
}

André Nassif

\section{Introduction}

The main goal of this paper is to discuss Brazil's economic situation in the recent period. Although the analysis is centered on the current Brazilian business conditions (known as the conjuntura econômica in Portuguese), the paper covers the period after 2014, during which the country's economic problems have significantly worsened. The remainder of the paper is divided into the following sections. Section 2 seeks to analyze and discuss the main structural and short-term causes that explain the worsening of Brazil's economic situation in 2014, as well as the deep recession that followed it. Section 3 critically analyzes the macroeconomic policy adopted by Temer's government, assuming that there are both fiscal and monetary policy alternatives. Section 4 concludes the paper and discusses economic policy alternatives for growth recovery of the Brazilian economy, other than those chosen and adopted by Temer's economic team in 2016 and onwards. It also presents a brief economic outlook for 2017 and 2018.

\section{An analysis of Brazil's deep recession in the recent period}

The Brazilian crisis today is one of the most serious of the last century because it has not only reached the economic, but also the social and political spheres. On the political front, although the forces that pushed for the impeachment of President Dilma Rousseff sought to do so under an appearance of respecting the legal and institutional orders, their arguments were never accepted by a significant part of Brazilian society nor the majority of the international community. This is because the main political leaders of the impeachment process, by being highly suspected of involvement in the corruption scandal surrounding Petrobrás Oil Company, are also under risk of being implicated in the so-called Operation Car Wash (Operação Lava-Jato), as it was named by the Federal Police Investigation (led by investigators in the Curitiba branch, state of Paraná).

On the economic front, the current Brazilian economic recession has already been considered the deepest and most long-lasting in Brazil's economic history. Table 1 shows Brazil's recent basic macroeconomic indicators. Between 2015 and 2016, Brazil accumulated a contraction of $7.5 \%$ in its real GDP, representing a dramatic accumulated fall in its per capita income of $9.2 \%$ in just these two years. In fact, this contraction was much more intense than that of the so-called "lost decade" (1981-1992 period), when the per capita income had a 7.5\% accumulated negative growth rate.

\footnotetext{
Department of Economics, Fluminense Federal University and Director of the Brazilian Keynesian Association. E-mail: andrenassif27@gmail.com The author thanks Luhan Martins Reigoto for his competent research assistance, and Carmem Feijó, Dani Rodrik, Eliane Araújo, Fernando J. Cardim de Carvalho and Laura Carvalho for helpful comments and suggestions. The author is responsible for all remaining errors. This paper was written in April 2017.
} 
Table 1. Brazil: Basic macroeconomic indicators (2014-2017)

\begin{tabular}{|lcccc|}
\hline & $\mathbf{2 0 1 4}$ & $\mathbf{2 0 1 5}$ & $\mathbf{2 0 1 6}$ & $\mathbf{2 0 1 7}$ \\
Real GDP growth - in \% & 0.50 & -3.77 & -3.59 & 0.45 \\
Consumer inflation rate (IPCA) - in \% & 6.41 & 10.67 & 6.29 & 4.15 \\
Primary fiscal balance - in \% of GDP & -0.56 & -1.85 & -2.48 & -2.34 \\
Nominal fiscal balance (including interest expenditures) & & & & \\
in \% of GDP & -5.95 & -10.22 & -8.95 & -8.57 \\
Gross debt of public sector - in \% of GDP & 56.28 & 65.45 & 69.64 & 76.90 \\
Net debt of public sector - in \% of GDP & 32.59 & 35.61 & 46.01 & 51.41 \\
Current account balance - in \% of GDP & -4.24 & -3.31 & -1.30 & n.a \\
Gross fixed capital formation - in \% of GDP & 19.90 & 18.10 & 16.40 & n.a. \\
\hline
\end{tabular}

Source: Elaborated by the author based on the databases of Brazil's Central Bank, the Brazilian Institute of Geography and Statistics (IBGE) and the Independent Fiscal Institution of Brazil's Federal Senate.

Notes: i) * means that indicators are estimated by markets; ii) n.a.: not available

It is not surprising that such an economic downturn has severely worsened social indicators in Brazil. Figure 1 shows that unemployment rates have almost monotonically jumped since the beginning of 2015, from 6.5\% to 13.2\% in February 2017 (a total of 13.5 million unemployed workers), a level undoubtedly related to depressed economies. According to the Brazilian Institute of Geography and Statistics (IBGE), in the moving quarter of December-January-February 2017, total real payroll of all employed workers kept stable compared with the same quarter of 2016, after having shown almost successive drops in its real growth rates between the last quarter of 2014 and the third quarter of $2016^{1}$.

An intense debate over the causes of the recession has been taking place among Brazilian economists. On the orthodox front, the recession resulted from two basic factors: first, a highly expansionist fiscal policy between 2012 and 2014, characterized by a loss of control of primary public expenditures; and second, a policy through which the Monetary Policy Council (COPOM, in the Portuguese acronym) of Brazil's Central Bank, even when inflation expectations were not well-anchored, prematurely initiated the reduction of basic interest rates (SELIC) from 12.50\% in September 2011 to $7.25 \%$ in March 2013. ${ }^{2}$ COPOM justified this flexibility of monetary policy with the expected recessive effects on Brazil from the Euro Zone crisis. Financial markets, interpreting such a precipitous policy of reduction in interest rates as resulting from pressure from the federal government, popularized the narrative of excessive interference of President Dilma Rousseff with the de facto independence of Brazil's Central Bank. Such interference could lead to a loss of credibility of monetary

\footnotetext{
1 According to IBGE - Continuous National Household Monthly Sample Survey (PNAD Contínua), February 2017 and IBGE - Continuous National Household Quarterly Sample Survey (PNAD Contínua), $4^{\text {th }}$ Quarter of 2016. Available at, respectively, ftp://ftp.ibge.gov.br/Trabalho_e_Rendimento/Pesquisa_Naci onal_por_Amostra_de_Domicilios_continua/Mensal/Comentarios/pnadc_201702_comentarios.pdf, and $\mathrm{ftp} / / / \mathrm{ftp}$.ibge.gov.br/Trabalho_e_Rendimento/Pesquisa_Nacional_por_Amostra_de_Domicilios_continu a/Trimestral/Comentarios_Sinteticos/pnadc_201604_trimestre_comentarios_sinteticos_Brasil.pdf

${ }^{2}$ As a matter of fact, the orthodox interpretation does not limit these two causes as the only ones responsible for the current recession in Brazil, for some authors (e.g. Bacha and Bonelli, 2016) also include some microeconomic factors, especially excessive government intervention in the goods market, which has also contributed (among other factors) to explaining low growth rates of productivity. However, I prefer to indicate expansionist fiscal and monetary policies for summing up the main macroeconomic factors generally appointed by orthodox economists for explaining Brazil's current economic recession because both of those policies characterize the period 2011-2014 (that is to say, the period of Dilma Rousseff's first-term) as that during which, according to Bonelli and Bacha (2016:155), Brazil would have suffered from "domestic economic mismanagement."
} 
policy. ${ }^{3}$ De Bolle, for instance, (2016:112-114) agreed with the financial markets' narrative by declaring that the inflation targeting regime, which had magisterly been managed before 2011 , was abandonded in practice (although not officially), in $2012 .{ }^{4}$

Figure 1. Unemployment rates in Brazil - 2014-2017 (in \%)

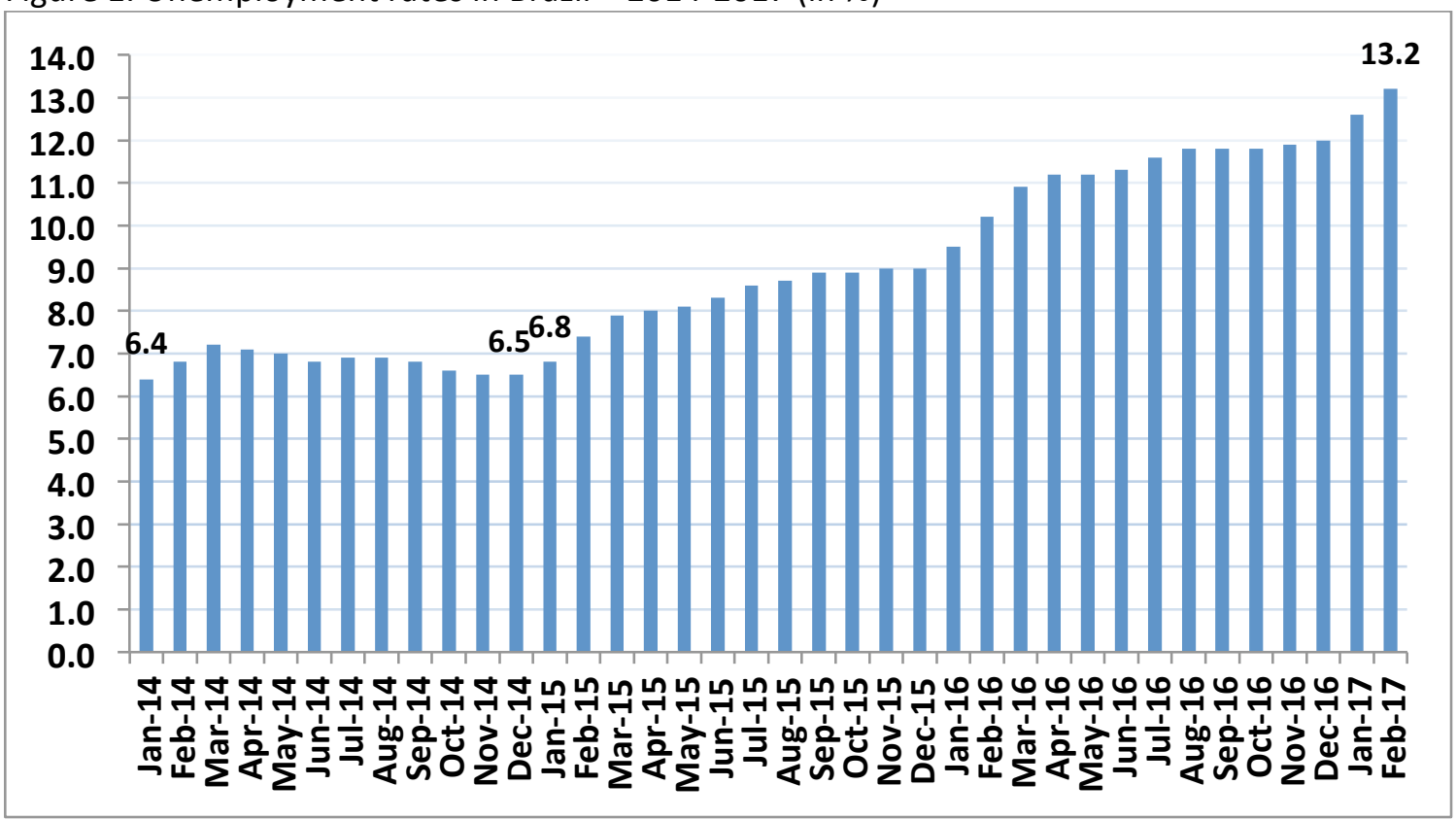

Source: IBGE

The financial markets' criticism, however, is not convincing because as soon as the risk of contagion of the Euro crisis was overcome and by recognizing that consumer inflation rates (IPCA) in Brazil continued to be resilient and much above the annual target of $4.5 \%$, COPOM reinitiated a new sustained cycle of interest rate increases between April 2013 (still under Rousseff's first term) and November 2016, from 7.50\% to $13.75 \%$. Even taking into account that this latter level corresponded to an ex-post real interest rate of around $7.0 \%$ p.y. and an ex-ante real interest rate of approximately $8.3 \%$-the highest real interest rate among the emerging and developed countries-, the yearly accumulated consumer inflation rate (IPCA) was still above (6.99\%) the upper level of the inflation target $(4.5 \%)$ by November $2016 .{ }^{5}$

Indeed, since the roots of the current Brazilian crisis are associated with both structural and short-term causes, that orthodox interpretation is narrow. The main structural cause is related to the premature deindustrialization of the Brazilian economy, a phenomenon

\footnotetext{
${ }^{3}$ The financial markets' interpretation is widely documented by the press from 2011 and onwards. For instance, according to Epoca (January 1, 2016), a Brazilian magazine, "Tombini accompanied Dilma Rousseff's political activism, by cutting basic interest rates from $13.50 \%$ to $7.25 \%$ between 2011 and 2012 [the level of 7.25\% was kept until April 2013].

${ }^{4}$ Affonso Celso Pastore, a known Brazilian orthodox economist and former governor of Brazil's Central Bank, also declared that Brazil's Central Bank (under Tombini's governing) "needs to give credibility to the inflation target regime" (quotation reported by the Brazilian newspaper O Estado de São Paulo, March 20, 2015).

${ }^{5}$ These data were calculated by Brazil's Central Bank. According to Infinity Asset Management, in February 2017, Brazil still had the highest ex-post and ex-ante real interest rate among emerging and developed countries (respectively, 6.6\% and 7.3\%), followed by Russia (respectively, $4.8 \%$ and $4.9 \%$ ). India, although being ranked as the third highest ex-post real interest rate (3.0\%), has the sixth highest ex-ante real interest rate among the same group of countries (1.5\%). See Infinity Asset Management, http://moneyou.com.br/wp-content/uploads/2017/02/rankingdejurosreais210217.pdf
} 
that strongly accelerated after Lula da Silva's government. ${ }^{6}$ Indeed, from 2005 to 2016, the share of the manufacturing sector (measured in value added) in total GDP was reduced from $15.3 \%$ to $9.8 \%$ (in 1995 constant prices). If we take into account that the static and dynamic gains from increasing returns to scale resulted from an enlarged and diversified manufacturing sector, the unequivocal premature deindustrialization in Brazil has been contributing not only to the low rates of labor productivity growth, but also to reprimarizing the Brazilian export basket. $^{7}$

As this paper is on Brazil's current business conditions, I am more interested in the short-term causes for the Brazilian economic crisis. ${ }^{8}$ Rousseff's government, in fact, committed several mistakes with the goal of recovering from the rapid deceleration of the Brazilian economy. According to IBGE, after showing a real GDP growth of $7.5 \%$ in 2010 (the last year of Lula's second term), the growth rate dropped to $1.9 \%$ in 2012 . To reverse such a poor performance, Dilma's economic team employed, from this latter year on, several stimulus instruments for boosting both aggregate demand and supply, particularly credit expansion, tax exemption for the purchase of consumer durable goods and tax exemptions to most sectors of the economy. ${ }^{9}$ Even though the adoption of this set of stimulus mechanisms was correctly justified in the aftermath of the 2008 global crisis (say, between 2009 and 2010), its continuation from 2012 onwards had become counterproductive, as it elicited a very weak response from private investment. It is true that, at 1995 constant prices, the investment rate (investment as a proportion of GDP) increased from 20.6\% between 2007 and 2010 (the second term of Lula's government) to $22.4 \%$ between 2011 and 2014 (the first term of Dilma's government). ${ }^{10}$ But in each of the two years of Dilma's government (2011-2012 and 20132014), the investment rate was kept unchanged in real terms, notwithstanding the generalization of the above mentioned economic stimuli.

Even so, the deepening of the Brazilian economic crisis from mid-2015 onwards cannot be entirely blamed on the mistakes of Rousseff's first term. The increase in consumer inflation rates (IPCA) from $6.4 \%$ to $10.7 \%$ between 2014 and 2015, rather than only being driven by unanchored expectations, was partially explained both by the government's decision to permanently correct prices that had been frozen in the previous year (particularly, electrical energy and fuels), and by the sharp depreciation of the Brazilian real throughout $2015 .{ }^{11}$ The response of monetary policy was to accelerate the increase of the policy interest rate. Under

\footnotetext{
${ }^{6}$ Yet both orthodox and heterodox economists indicate the real appreciation trend of the Brazilian currency as being one of the main causes of Brazil's premature deindustrialization. See, for instance, Bacha (2013), Bresser-Pereira (2010) and Nassif, Feijó and Araújo (2015).

${ }^{7}$ The following indicators (in percentage p.y.) show how stagnant labor productivity growth has been in Brazil in the last decades: 1996-2002: 0.9\%; 2003-2010: $-1.2 \%$; 2010-2013: 1.3\%; 1996-2013: 0\%. As to the export basket, the share of primary products plus natural resource-based manufactured goods in Brazilian total exports jumped from $40.3 \%$ in 2000 to $62.5 \%$ in 2014 . All these indicators can be found in Nassif, Bresser-Pereira and Feijó (2017).

${ }^{8}$ This is my interpretation on the short-term causes of Brazil's economic crisis. For readers interested in other alternative interpretations on the heterodox side, see Serrano and Summa (2016) and Carneiro (2017).

${ }^{9}$ Between 2011 and 2014, 56 sectors of the economy were benefited with some kind of tax exemption, especially payroll tax.

${ }^{10}$ These data were calculated by the author according to IBGE database.

${ }^{11}$ In virtue of the high political uncertainty related to the possibility of Dilma Rousseff's impeachment, the Brazilian currency depreciated from 2.66 Brazilian reals to 3.90 Brazilian reals in relation to the US dollar (or a depreciation of 46.6\%) between January 2015 and December 2015 (monthly average). These data can be found on the Brazil's Central Bank website (http://www.bcb.gov.br; Outlook indicators/economic indicators/Table V.31).
} 
both the governor Alexandre Tombini, linked to Dilma Rousseff's government, and the new governor Ilan Goldfajn, nominated by Michel Temer in June 2016, COPOM, which had already increased the nominal interest rate (SELIC) from 10.50\% to $11.75 \%$ between January 2014 and December 2014, subsequently increased Brazilian policy rates from $12.25 \%$ in January 2015 to $14.25 \%$ in August 2016. The tightening of monetary policy within a very recessive context has been strongly debated among Brazilian economists. Even taking into account that most of the inflation acceleration throughout 2015 was explained by supply shocks, COPOM was right in practicing a more tightened monetary policy throughout that year with the goal of anchoring inflation expectations. However, the main critique is that the increase in the policy interest rate was excessive, leading to a very high real policy interest rate. De Bolle (2017), for instance, argued that, in the absence of fiscal space for stimulating public investments, "despite the deepest recession on record, the monetary policy stance led to much tighter conditionsmeasured by the rise in real interest rates-which may have contributed to the sharper contraction observed during the second half of last year [2016]." That is to say, the drug prescription for the patient was so disproportionally strong that, despite having in fact contributed to anchoring inflation expectations towards the target of $4.5 \%$ p.y., Brazil's Central Bank was also partially responsible for aggravating the Brazilian recession, damaging the balance sheets of many enterprises and putting unemployment rates at sky-high levels. ${ }^{12} 13$

The effects of such a hard monetary policy have gone much beyond the abovementioned jeopardization of the real side of the Brazilian economy. Even the dramatic jump in the gross debt of the public sector, as a proportion of GDP, from $56.3 \%$ to $65.5 \%$ between 2014 and 2015 cannot be totally explained by the increase in the primary fiscal deficit (also relative to GDP) from $0.6 \%$ to $1.9 \%$ in the same period for two reasons. The first reason, as clearly shown in Table 1, is that although between 2014 and 2015 the growth of the primary fiscal deficit was much more significant (an increase of $216.7 \%$ !) than the nominal fiscal deficit (which includes interest expenditures and which increased from 6\% of GDP to $10.2 \%$ of GDP, an increase of 70\%), much of the increase in the former resulted from the notable deficit of social security (2014: $-1.0 \%$ of GDP; 2015 : $-1.4 \%$ of GDP). ${ }^{14}$ This means that a significant part of the Brazilian primary fiscal deficit is structural. The second reason is found by comparing the public sector borrowing requirements in 2015. According to Brazil's Central Bank, it shows that while the part necessary to cover the primary fiscal deficit corresponded to $1.9 \%$ of GDP, the part responsible for covering the nominal interest payments was around $8.4 \%$ of GDP. ${ }^{15}$

On the external front, the most pronounced result was the rapid adjustment of the current account deficit, which was reduced from 4.2\% of GDP in 2014 to 1.3\% of GDP in 2015 (see Table 1). As will be shown hereinafter, differently from the current account correction in the period 1999-2003, the rapid adjustment trajectory between 2014 and 2016 was basically driven by the sharp fall in imports, rather than an export boom.

\footnotetext{
12 According to the Inflation Report of March 2017, released by Brazil's Central Bank, "inflation expectations collected by the Focus survey are around $4.1 \%$ for 2017 and around the $4.5 \%$ target for 2018. For 2019 and longer horizons, expectations dropped slightly below 4.5\%, possibly reflecting expectations about the setting of future inflation targets." See Brazil's Central Bank (2017:7).

${ }^{13}$ As stated by IMF (2016:26), "although levels of private debt (including that of nonfinancial firms and households) in Brazil are comparable to those of other emerging market economies, their pace of increase over the last decade has been double that of its peers. This is a source of significant vulnerabilities, as documented by extensive empirical evidence."

14 These data are available on Brazil's Central Bank's website. See (http://www.bcb.gov.br; Outlook indicators/economic indicators/Table IV.3).

15 These data are available on Brazil's Central Bank's website. See (http://www.bcb.gov.br; Outlook indicators/economic indicators/Table IV.27).
} 
Temer's economic team (especially the Minister of Finance, the Minister of Planning and the staff of Brazil's Central Bank) bases almost all their effort to restoring economic growth on the hypothesis that by implementing a strong fiscal adjustment (the so-called "expansionist fiscal consolidation") and a monetary policy based on strict rules to make inflation expectations as well as actual inflation converge with the inflation target, confidence will be restored. Additionally, since the arrangement with the long-term fiscal adjustment would enlarge the room for COPOM to reduce basic interest rates (on the condition that actual inflation rates will quickly match the inflation target), economic agents would be pushed to increase aggregate demand.

As to the fiscal adjustment, Temer's government, having obtained strong political support by both the Lower House and the Senate (at least until the time of writing this paper), was successful in approving Constitutional Amendment no. 95, of December 2016. The Amendment states that over the next 20 years starting from 2017, the growth of yearly total primary expenditures will be adjusted according to the yearly consumer inflation rate (IPCA) of the previous year. In practice, this implies a freeze on total primary expenditures in real terms over the next 20 years. ${ }^{16}$ The Law of Spending Cap (as was popularized by this Constitutional Amendment) does not prohibit yearly real growth of specific expenditures (say, education, health, infrastructure, among others), but only the real growth of total primary expenditures. Needless to say that the main goal of this fiscal rule is to reduce total primary expenditures as a proportion of the Brazilian GDP. In addition, given that the main item responsible for the Brazilian primary fiscal deficits is the deficit of social security, the expected results of this new fiscal rule will depend on the approval of the Social Pension Reform by Congress. Many economists (including the author of this paper) doubt the political and social viability of such a draconian fiscal adjustment working, for inasmuch as the population tends to grow in the medium and long-term, there will be major political demand and competition for increasing several expenditures in real terms, especially health, education, infrastructure and other social expenditures. ${ }^{17}$

Figure 2 shows clearly that both indices of confidence (current conditions and future expectations) have improved since the beginning of 2017. However, the turning point away from the previous environment of bad expectations occurred approximately between the end of 2016 and January 2017. Thus, it is still too early to conclude that the state of confidence has actually improved in the Keynesian sense, that is, a state through which better expectations extend out across most entrepreneurs in such a way the old convention of bad expectations has been removed and is definitely replaced by sound positive expectations. Needless to also say that when an economy is deeply depressed, as is the case of the Brazilian economy, macroeconomic policy should adopt instruments to help reactivate aggregate demand (see Krugman, 2009). Under such circumstances, the changing of convention towards a more longlasting state of confidence is also a consequence of economic recovery and growth.

\footnotetext{
${ }^{16}$ The Amendment incorporates the possibility of a revision of this rule within 10 years. It is important to note that, as inflation rates are dropping within a strong recessive environment (which implies decreasing fiscal revenues), the International Monetary Fund (IMF) estimates that Brazil will only be able to show primary fiscal surplus from 2020 on. See International Monetary Fund (2016, Table A.10:72).

17 In a comment to a first draft of this paper (by an e-mail to the author), Dani Rodrik pointed out that this aspect of Temer's fiscal reform "seems like the government has chosen a gimmick for the purpose of gaining market confidence." For Rodrik, Brazil's fiscal adjustment could be compared "in spirit to Argentina's convertibility law [the adoption in 1991 of a convertibility law, pegging the currency, the peso, to the American dollar] which eventually proved disastrous of course."
} 
Figure 2. Index of Industrial Entrepreneurs' Confidence: 2014-2017

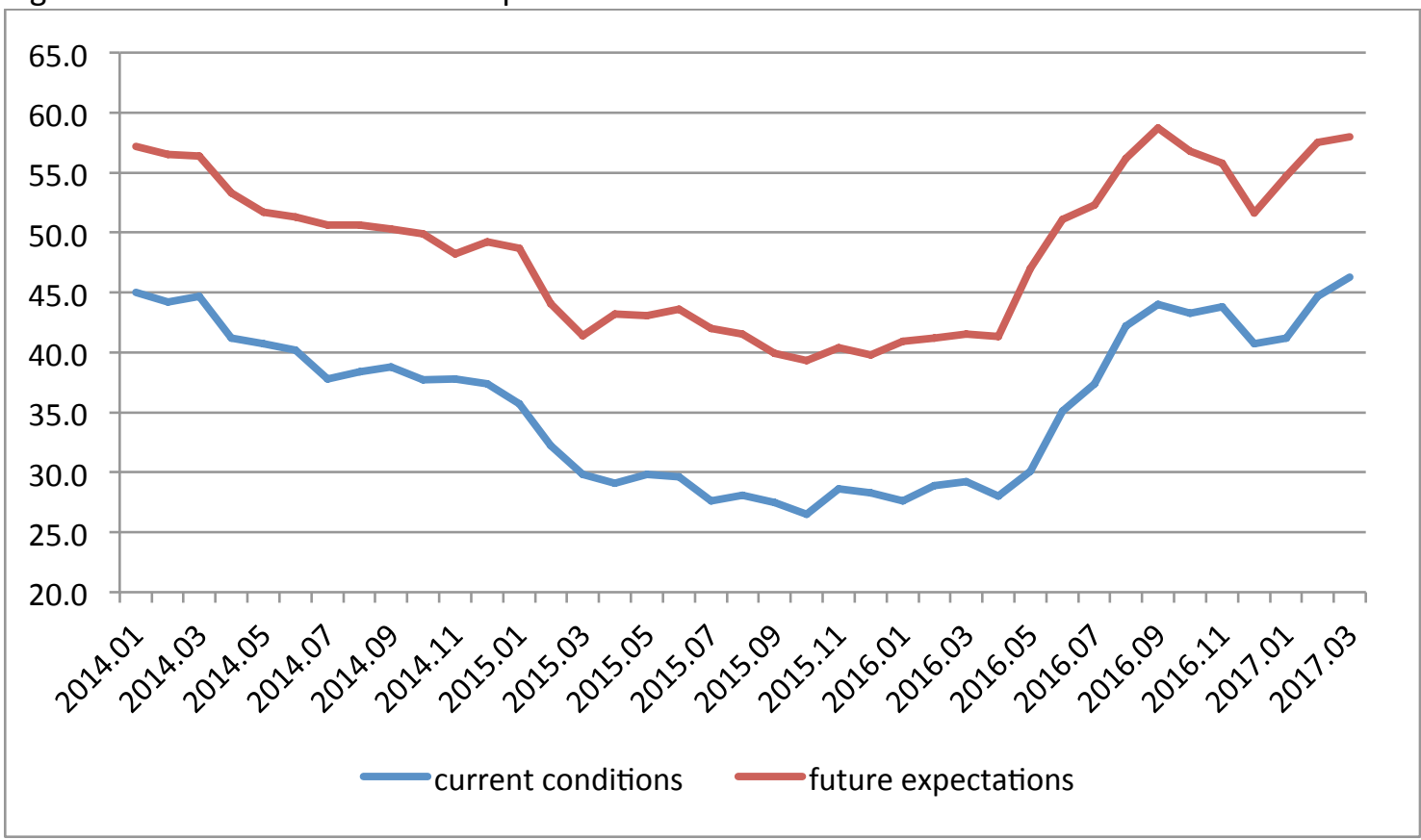

Source: Brazil's National Confederation of Industry (CNI)

Figure 3 presents the recent dynamics of the Brazilian real GDP classified by components of aggregate demand.

Figure 3. Brazil's GDP Growth Classified by Components of Aggregate Demand Yearly Accumulated Growth Rates Over Four Quarters: 2014-2016 (in \%)

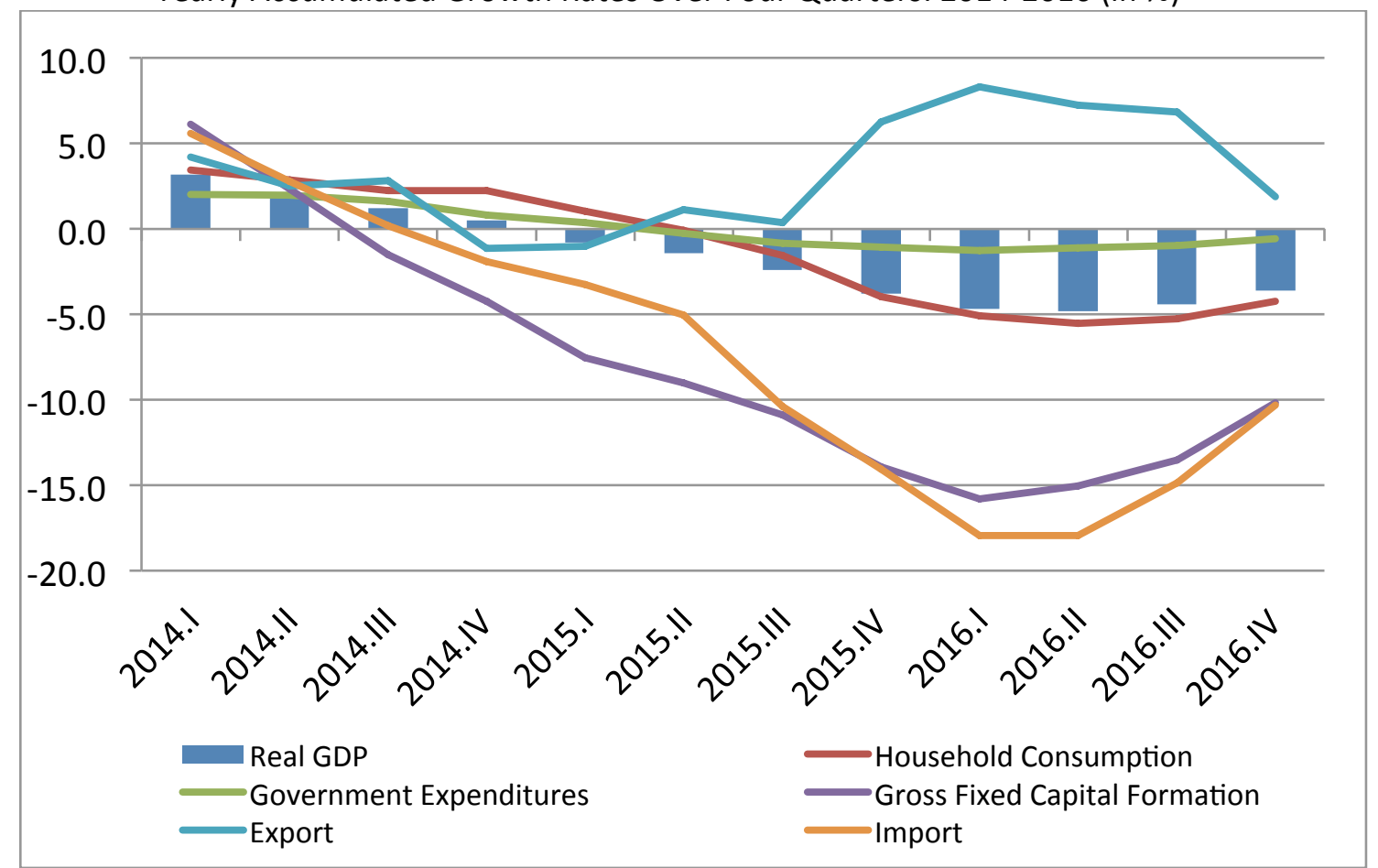

Source: IBGE

It can clearly be noted that all components of domestic aggregate demand still reflect the behavior of a very depressed economy, especially gross investment and household consumption. Figure 3 shows that gross investment, imports and household consumption, 
despite apparently having bottomed out by the third quarter of 2016, are far from signalizing a sound recovery, given their respective very negative accumulated yearly growth rates in the last quarter of 2016 (around $-10 \%$ in the case of gross investment and imports, and almost $-5 \%$ in the case of household consumption). Even the external component of aggregate demand (net exports) also confirms a behavior of a depressed economy because the drop in yearly accumulated growth rates of imports between the second semester of 2015 and the first quarter of 2016 was much deeper than the increasing rates of exports in the same period. From the first quarter of 2016 onwards, although imports have signalized some recovery (despite their still high negative growth rates), exports have shown decreasing yearly accumulated growth rates. As already mentioned, this behavior confirms that the rapid adjustment of the current account deficit between 2014 and 2016 was highly contractionary.

\section{Growth Recovery?}

Temer's economic team (the Ministry of Finance and Brazil's Central Bank, in particular) has assured that the Brazilian economy has already reached its bottoming out point and is prepared for recovery in the second quarter of 2017. These expectations are based on the following measures of economic policy: i) since inflation expectations were anchored and actual consumer inflation rate (IPCA) is expected $(4.1 \%)$ to be below the target $(4.5 \%$, see Table 1) in 2017, and in face of the deep recession still under way, COPOM will accelerate the drop in short-term nominal policy rates; ${ }^{18}$ and ii) in addition to the improvement in confidence resulting from the fiscal adjustment and other economic reforms, the estimated injection of approximately 30 billion Brazilian reals (around US\$10 billion) in the economy, provided by Federal Provisional Measure no. 763, of December 2016, which permitted former employees that resigned prior to December 31, 2015 to withdraw their FGTS (Brazilian Indemnity Funds), will recover household consumption and, therefore, push the real output up.

However, this optimistic outlook must still be viewed with caution for several reasons. First, unemployment rates continue to increase and reached $13.2 \%$ in the moving quarter ending February 2017, corresponding to 13.5 million unemployed workers. As disposable income has significantly dropped in the last two years and most families are highly indebted by borrowings taken in Dilma Rousseff's period of credit boom (2011-2014), there is insufficient room to boost household consumption in the near future. ${ }^{19}$

Second, the sharp drop in gross investment (as expressed by the yearly accumulated growth rates as well as by the proportion of GDP; see Figure 3 and Table 1, respectively), combined with the decrease in the accumulated growth rates of the other components of aggregate demand (notably household consumption, but also government expenditures), caused the use of installed capacity of Brazil's manufacturing sector to reach a very low level in February 2017 (73.3\%). This indicates a level of average idle capacity of $26.7 \%$, which can be considered one of the highest in recent Brazilian economic history and is very close to the country's deep recessions (see Figure 4 below). ${ }^{20}$

\footnotetext{
18 In its Inflation Report of March 2017, Brazil's Central Bank states that such an inflation stabilization scenario "reinforces the possibility of a moderate intensification of the pace of monetary easing, in comparison to the pace set in the two latest Copom meetings." See Brazil's Central Bank (2017:8).

${ }^{19}$ The expected injection of approximately 30 billion Brazilian reals resulting from FGTS withdrawals is relatively very small ( $0.5 \%$ of Brazil's GDP) to drive a strong recovery of household consumption, given the size of the Brazilian economy.

${ }^{20}$ Brazil's Central Bank has registered time series of the use of installed capacity of the manufacturing sector in Brazil since 2001. To give an idea of the current deep recession, the lowest use of installed capacity of Brazil's manufacturing sector during the 2009 recession was 76\% (March 2009). Brazil's Central Bank also registers time series of the use of installed capacity for Brazil's overall economy. There
} 
Figure 4. Index of Use of Installed Capacity in the Brazilian Manufacturing Industry 2014-2017 (in \%)

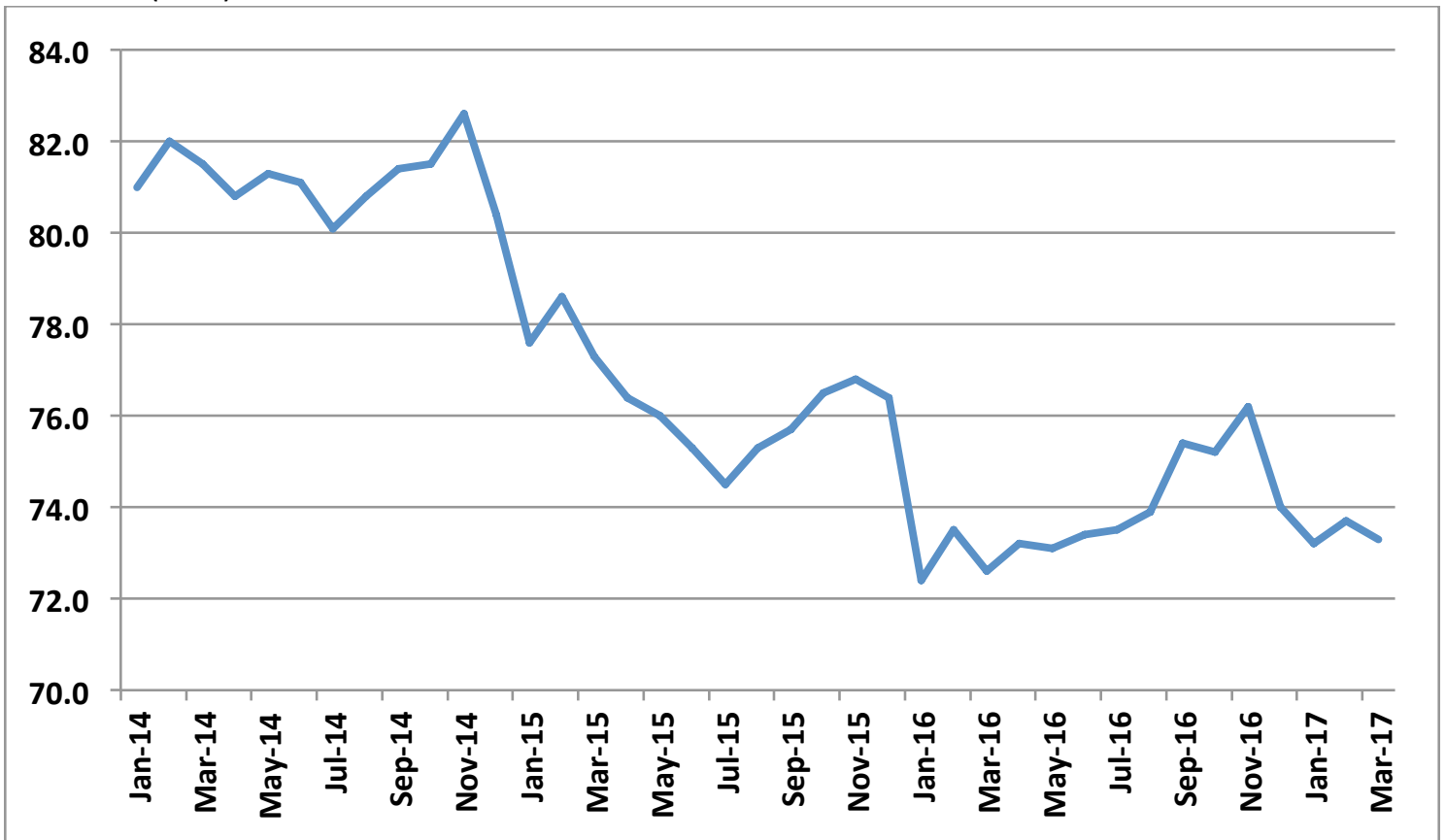

Source: Getulio Vargas Foundation (FGV)

Third, the evidence of no support (at least until the time of writing this paper) that the Brazilian economy has begun its process of recovery can also be shown by the behavior of the accumulated growth rates of real output of selected Brazilian industries after 2014.

Figure 5. Real Output in Selected Brazilian Industries: Yearly Accumulated Growth Rates Over Four Quarters (2014-2016) - in \%

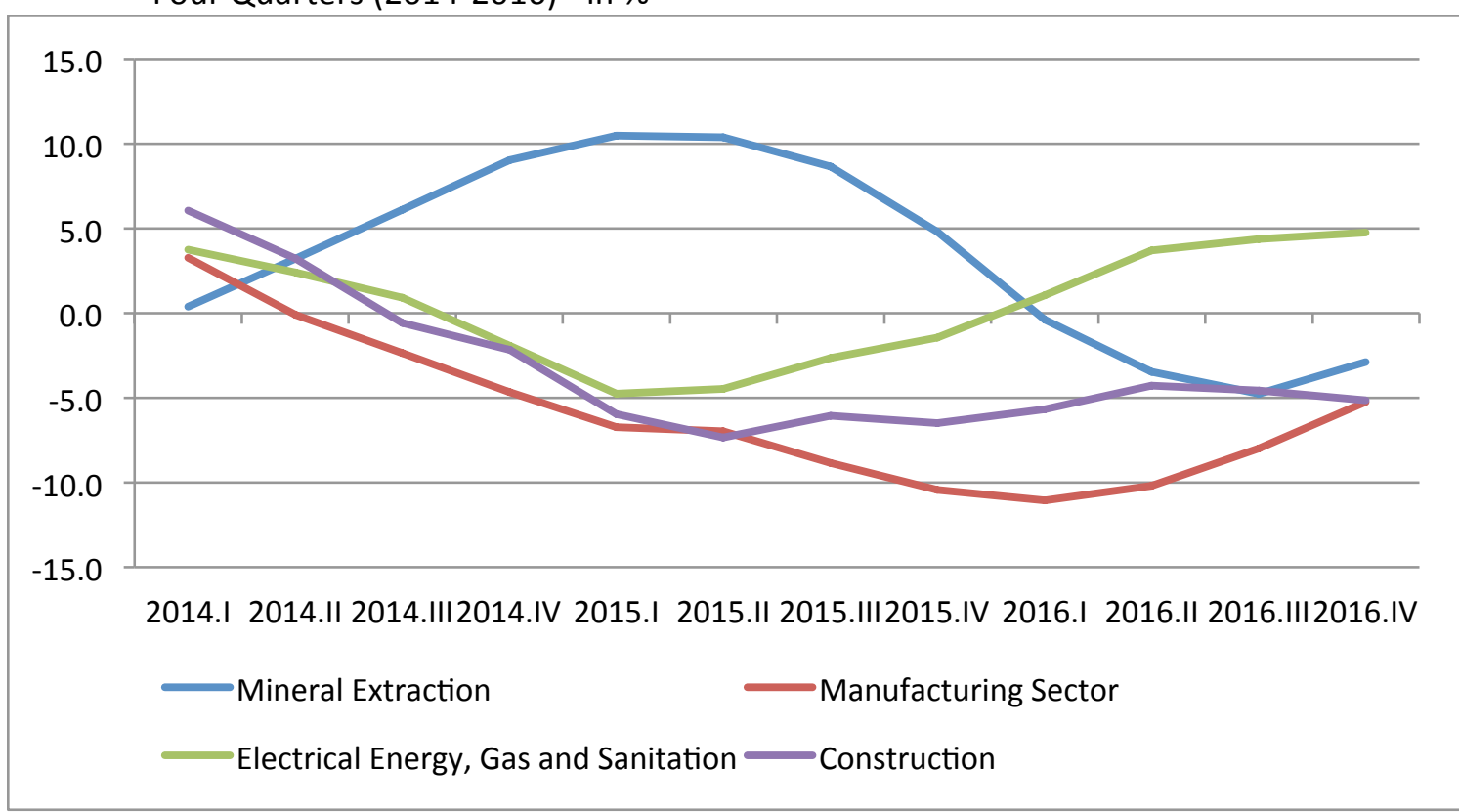

Source: IBGE

we can find the lowest level reached by this indicator in Brazil's deep recessions, such as that of the period 1981-1983 (72.0\% in the third quarter of 1983), the period $1990-1992$ (61\% in the second quarter of 1990) and the current recession (73.2\% in the first quarter of 2017). For details, see the website of Brazil's Central Bank (httpp://www.bcb.gov.br)/Time Series. 
Except for electrical energy, gas and sanitation, both industrial (manufacturing plus mineral extraction industries) and construction sectors continued to register high negative growth rates. While the construction industry continued to contract in the end of 2016, the manufacturing sector, which together with the former could be the main drivers of Brazilian economic recovery, signalized, at best, that it has already reached its bottoming out point, as discussed earlier.

This explains why the index of output of the Brazilian manufacturing sector was still so low in the beginning of 2017. Figure 6 shows that this sector was still nearly stagnated by February 2017 and was $17.2 \%$ below the 2012 level.

Figure 6. Index of Output of Brazil's Manufacturing Sector with Seasonal Adjustment: 2014$2017(2012=100)$

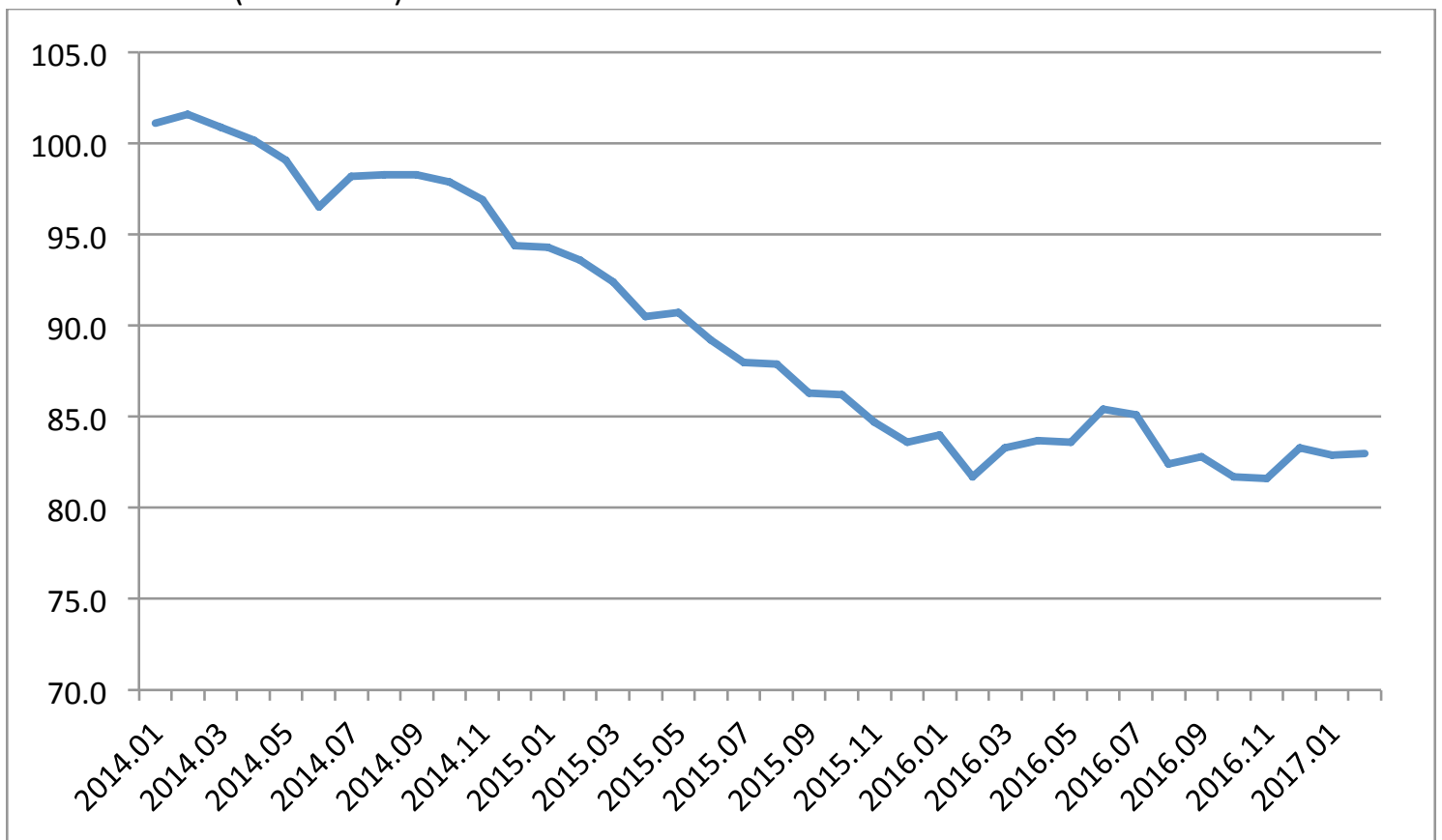

Source: IBGE

Even the export growth, which could, in principle, contribute to minimizing the recessive impacts on employment, has not shown great capacity to drive Brazilian economic recovery in virtue of two reasons: first, because of the slow annual growth rates registered by the world economy in the recent period; ${ }^{21}$ and second, as Figure 7 shows, after the real exchange rate adjustment observed throughout 2015 (notwithstanding an episode of real exchange rate overshooting in January 2016 if Brazil's consumer price index is taken as the relevant deflator), the Brazilian real has returned again to an appreciation trend from mid2016 onwards. ${ }^{22}$ By February 2017, the Brazilian real was only $8.8 \%$ overvalued in relation to the real equilibrium observed in June 1994 if Brazil's consumer price index (IPCA) is taken as the deflator, but $38.8 \%$ overvalued if Brazil's wholesale price index (IPA-DI) is considered the relevant deflator.

\footnotetext{
21 According to the World Bank (World Economic Indicators), between 2014 and 2016, the world economy grew at $2.5 \%$ p.y. on average, against $4.2 \%$ p.y. on average as registered in the three years before the 2008 global crisis.

22 As Nassif, Feijó and Araújo (2017) showed, this real appreciation trend has been the Brazilian "normal" since 1999.
} 
Figure 7. Index of Real Effective Exchange Rates: 1999-2017 (1994=100)

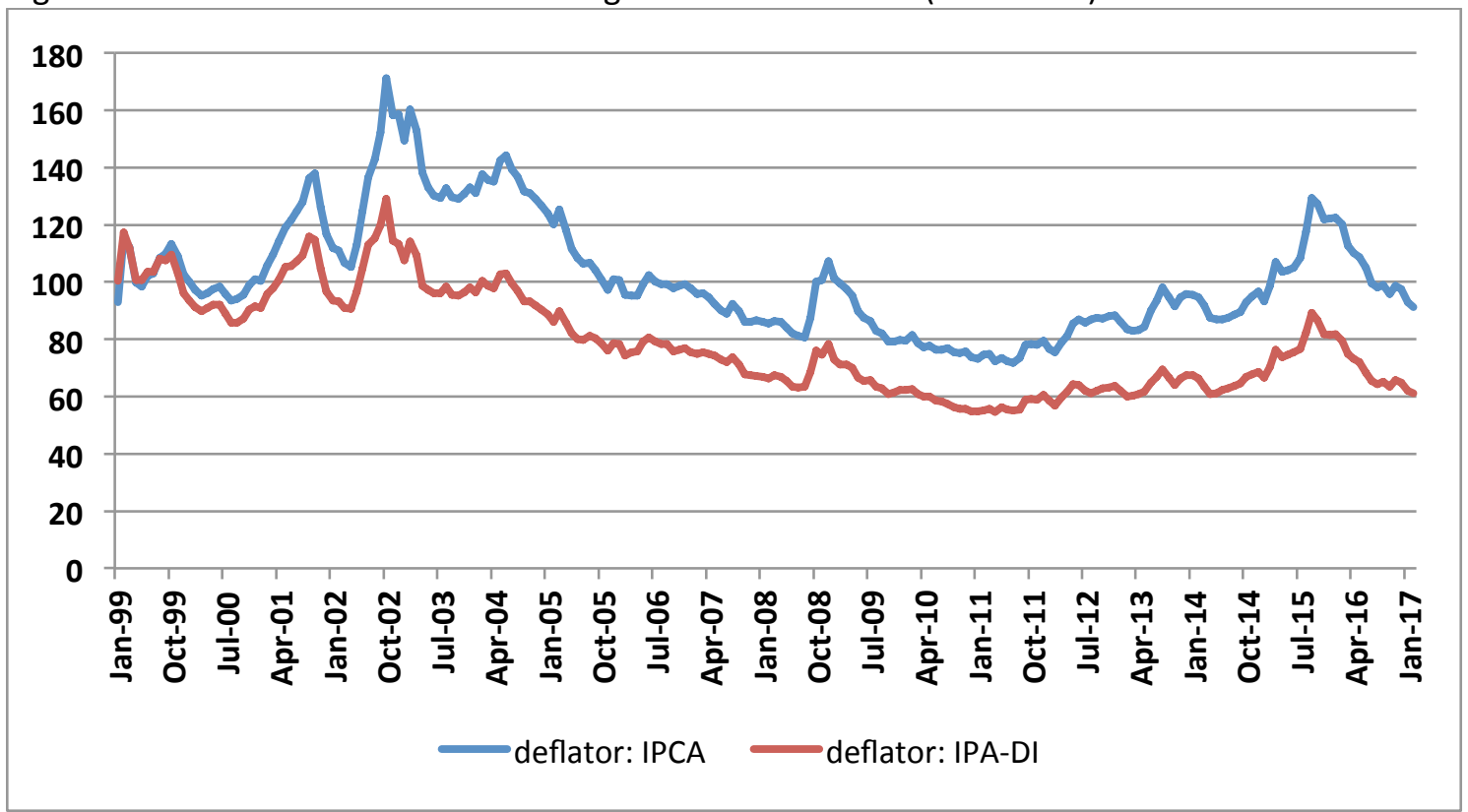

Source: Brazil's Central Bank

\section{Conclusion and alternative policy proposals}

Apart from the controversies, most Brazilian economists (including the author of this paper) agree with the importance of a long-term fiscal adjustment, believing it to be an important instrument not only for restoring and stabilizing confidence, but also for augmenting the room to maneuver so that Brazil's Central Bank can bring high real interest rates to lower levels compatible with international standards. The main support for the need of a long-term fiscal adjustment is that, even by recognizing that the main pressure on the increase in public sector gross debt (as a proportion of GDP) in Brazil after 2015 has been coming from the jump in nominal interest rates payments, the trajectory (and not only the level) of gross public debt must be considered unsustainable. After having increased from $56.3 \%$ to $69.6 \%$ of GDP between 2014 and 2016, Brazil's gross public debt is expected to reach 76.9\% of GDP in 2017. ${ }^{23}$

However, it is worth noting that a successful long-term fiscal adjustment has many ways of being implemented. The main issue is that the Temer government chose the worst one. A long-term fiscal adjustment through which all primary public expenditures are frozen for 20 years, besides being socially and politically difficult to preserve, denies to future governments, elected democratically by the Brazilian population, the possibility of using fiscal policy as an important instrument of countercyclical policy.

Besides that, in an environment of deep recession, as is the current case of Brazil, the best option to quickly reduce unemployment rates as well as reactivate private aggregate demand would have been an increase of public investment in infrastructure. That is to say, the government should have recognized that a period of countercyclical primary deficit, in which the current expenditures immediately begin to be adjusted and public investments increase, would have been the best and quickest alternative to reactivate aggregate income and employment in Brazil. Even the International Monetary Fund (2015:8) recently recognized that "in a deep and lasting recession, fiscal consolidation is likely to have a negative short-term

\footnotetext{
23 This means that the relationship between (high) interest rates and the trajectory and level of gross public debt is a puzzle because, all else being equal, the former causes a rapid pace of growth of the latter, but, in turn, the higher the level of gross public debt, the more the pressure on the increase of interest rates.
} 
impact on growth when there are large negative output gaps," as is the case of Brazil today. Needless to say that the virtual lack of political support not only made such an alternative impossible in Dilma Rousseff's government, but was also the cause of her impeachment. But that is not the case with Michel Temer.

There are two ways for a long-term fiscal adjustment that could have been analyzed as better alternatives than that chosen by Temer's economic team. The first one is the recent long-term fiscal adjustment adopted by India, through which the government establishes targets for reducing the nominal fiscal deficit (which includes interest expenditures) to a maximum of $3 \%$ of GDP in the long run. This option, however, is very difficult to be successfully implemented in Brazil in virtue of two reasons. The first is that, differently from India, a significant part of Brazil's total gross public debt is of short-term maturity. The second is that, as Brazil has a higher degree of external financial openness than India, the feasibility of a longterm fiscal adjustment through targets for reduction of the nominal fiscal deficit would require a close coordination between monetary and fiscal policies, which in practice would be much more difficult in Brazil than in India.

The second one, which could be more feasible in Brazil, is an arrangement with a longterm fiscal reform through which both primary revenues and primary expenditures are jointly restructured with targets adjusted to the Brazilian economic business cycle. ${ }^{24}$ On the side of fiscal primary revenues, the government should gradually reduce total fiscal exemptions, which increased from $4.0 \%$ of GDP in 2007 to $4.9 \%$ of GDP in 2014, and were expected to be reduced to only $4.3 \%$ of GDP in 2016 , a level still considered very high. ${ }^{25}$ On the side of fiscal primary expenditures, the government should adopt a long-term adjustment through which targets of primary surplus are continuously redefined in order to reduce Brazil's public sector gross debt to $30 \%$ of GDP in 20 years, a level considered prudent by the economic literature. ${ }^{26}$ At the same time, Brazil lost an opportunity to introduce Keynes's proposal of separating the public budgets into two: a public current budget (that is, the difference between current revenues and current expenditures, excluding public investment expenditures), on which would fall the targets for primary surplus throughout the entire period of fiscal adjustment; and a public investment budget (that is, the difference between current revenues and investment expenditures), which would be balanced over the entire period of adjustment, except in times of recession. In addition, any successful fiscal adjustment in Brazil should incorporate a definitive attempt at eliminating the totality of the Letras Financeiras do Tesouro (LFTS) of the Brazilian public sector bonds market. In fact, by being indexed to Brazil's shortterm policy interest rate (SELIC) and negotiated on a daily basis in the open market operations (overnight operations), the LFTs are considered a complete anomaly in the Brazilian governmental bonds system.

Additionally, it is important to recognize that, in virtue of the growing social security expenditures as well as the rising average replacement rates (that is, the ratio of the average benefits received by retirees and pensioners to the average wages of active workers), it is necessary to implement a pension reform in Brazil. However, like the long-term fiscal adjustment, a pension reform should also contemplate the restructuring of revenues and

\footnotetext{
${ }^{24}$ One could argue that this would be a return to the old policy of targets for primary fiscal surplus, introduced in 1999 in Brazil. In fact, it would. But, in my vision, it is a better solution than any other proposal that only contemplates control over expenditures, leaving the management of fiscal revenues out.

${ }^{25}$ These data, as well as those related to the fiscal exemptions granted to social security taxes (shown ahead), were calculated by Denise Lobato Gentil, from the Federal University of Rio de Janeiro. The author thanks professor Gentil for making these data available.

26 See,for instance, Fall and Fournier, 2015. See also the International Monetary Fund (2015).
} 
expenditures related to social security. In fact, in 2016, while estimated fiscal exemptions reached $4.3 \%$ of GDP, 2.3 percentage points of this total referred to government exemptions granted to enterprises with respect to social security taxes. This means that any pension reform in Brazil should also gradually eliminate such exemptions. As to the pension reform currently debated by Congress, the final text should take into account the high social and regional inequalities observed in Brazil.

As a matter of fact, this author agrees with the Keynesian view that a sound and responsible fiscal policy would help Brazil's Central Bank to structurally reduce both nominal and real interest rates in Brazil, which had in the beginning of 2017 the highest level among the emerging and developed countries. However, taking into account that Temer's economic team has already chosen the most conservative alternative of long-term fiscal adjustment, and that both inflation expectations and actual consumer inflation rates have already been reduced to levels very close to the inflation target in Brazil, COPOM should immediately accelerate the reduction of short-term interest rates. As the government has already discarded the possibility of using fiscal policy as a countercyclical policy instrument, a more expansionist monetary policy seems to be the only way to permit growth recovery of the Brazilian economy. However, due to several aspects of the actual Brazilian economy today (high private debt of both households and companies, high level of average idle capacity, etc.), the optimistic expectations of recovery made by the financial markets to begin in the second quarter of 2017 are not necessarily assured. If the Brazilian manufacturing sector keeps its bevavior stagnated in negative growth rates in the second and third quarters of 2017, another negative real GDP growth rate will be the most probable result for this year. If the sector reverses such a stagnation pattern and experiences a little more vigorous behavior over 2017 towards positive growth rates, growth recovery in Brazil in the near future (say in 2017 and 2018) will probably be very slow.

\section{Postscript: May 18, 2017}

In the beginning of May 2017, the final version of this paper was approved by the editors of the Brazilian Keynesian Review. The main conclusion of the paper was that, at best, the Brazilian economy seemed to be no longer worsening. On May 17, 2017, the Brazilian press released an explosive scandal according to which President Michel Temer had been recorded authorizing hush money to a jailed political ally in exchange for his silence about corruption accusations against himself and other politicians of his party. Whatever the political solution for this crisis turns out to be - Temer's resignation, another impeachment, a decision by Brazil's Electoral Supreme Court, new presidential elections or even the conclusion of Temer's term -, Brazil has already embarked on a serious political crisis and consequently entered an undetermined period of uncertainty that will practically nullify the weak possibilities of growth recovering in the short run.

\section{References}

Bacha, E. and Bonelli (2016). Coincident Growth Collapses: Brazil and Mexico since the early 1980s. Novos Estudos Cebrap Vol. 35(2), p.151-181.

Bacha,, E. (2013). "Bonança Externa e Desindustrialização: uma Análise do Período 20052011". In: E. Bacha e M. B. de Bolle (orgs). O Futuro da Indústria no Brasil: Desindustrialização em Debate. Rio de Janeiro: Civilização Brasileira, p. 97-120.

Brazil's Central Bank (2017). “Inflation Report. March, 2017”. Brasilia: Brazil's Central Bank.

Bresser-Pereira, L.C. (2010). Globalization and competition. Why some emerging countries succeed while others fall behind. Cambridge: Cambridge University Press. 
Carneiro, R. (2017). "Navegando a Contravento (Uma Reflexão sobre o Experimento Desenvolvimentista do Governo Dilma Rousseff)". Texto para Discussão no 289. Campinas: Instituto de Economia, Universidade Estadual de Campinas (UNICAMP).

De Bolle, M.B. (2016). Como Matar a Borboleta-Azul: Uma Crônica da Era Dilma. Rio de Janeiro: Intrínseca.

De Bolle, M. B. (2017). "Is the Brazilian Central Bank Coming to Grips with the Country's Balance Sheet Recession?". Peterson Institute for International Economics. Available at https://piie.com/blogs/realtime-economic-issues-watch/brazilian-central-bankcoming-grips-countrys-balance-sheet .

Fall, A and Fournier, J. (2015). "Macroeconomic Uncertainties, Prudent Targets and Fiscal Rule". Economics Department Working Papers no. 1230. Paris: OECD.

International Monetary Fund (2016). Fiscal Monitor: Debt- Use it Wisely. Washington, D.C.: International Monetary Fund, October.

International Monetary Fund (2015). "Fiscal Policy and Long-Term Growth". IMF Policy Paper. Washington, D.C.: International Monetary Fund, June.

Krugman P (2009). The Return of Depression Economics and the Crisis of 2008. New York: W.W. Norton \& Company.

Nassif, A., Bresser-Pereira, L.C. and Feijó, C. (2017). "The Case for Reindustrialisation in Developing Countries: Towards the Connection between the Macroeconomic Regime and the Industrial Policy in Brazil". Cambridge Journal of Economics, forthcoming.

Nassif, A., Feijó, C. and Araújo, E. (2017a). "A Structuralist-Keynesian Model for Determining the Long-Term "Optimal" Real Exchange Rate for Economic Development: The Case of Brazil". Cepal Review, December, forthcoming.

Nassif, A., Feijó, C. and Araújo,, E. (2015). "Structural Change and Economic Development: is Brazil Catching-up or Falling-Behind?". Cambridge Journal of Economics. V.39, p.13071332.

Serrano, F. and Summa, R. (2016). "Aggregate Demand and the Slowdown of Brazilian Economic Growth in 2011-2014." Nova Economia, v.25 (special edition), p.803-833. 